\section{The American Public School and the Deviant Child : \\ The Origins of Their Involvement}

EDWARD HOFFMAN, M.A. University of Michigan
Over the past decades, American public schools have become increasingly involved with children defined as mentally or emotionally impaired. By now every state has enacted legislation, either mandatory or permissive, providing for the establishment of local school services for such children. An extensive national system has evolved since the turn of the century. while services and funding have markedly expanded. Yet the field today is under unprecedented criticism, and both its defenders and critics generally remain unaware of its own history.

Under the direction of Professor William C. Rhodes of the University of Michigan, and supported by the Bureau of Education for the Handicapped, U.S. Office of Education (OEG-0-71-3680 [603]), the Conceptual Project in Child Variance has in part addressed itself to the historical growth of the major public institutions that deal with children viewed as mentally or behaviorally deviant. Institutions or service delivery systems singled out for study were: mental health, educational, legal/correctional, social welfare, sectarian agencies, and counter-cultural forms, such as communes. The author has been engaged in research on the educational system and its treatment-historical and current-of deviance in children.

One motive for this research resulted from the finding that little existed in either regular or special education literature that examined historical material of this nature. Furthermore, under the impetus of concerned parent groups, child advocates, and others current school programs for children considered "exceptional" have come under mounting criticism. It has been argued (Dunn, 1968; Mercer, 1970) with increasing success before the courts, that children of non-white, lower economic backgrounds are being misplaced into 
stigmatory and educationally inferior tracks for the mentally retarded or emotionally disturbed/socially maladjusted. In addition, the publicizing of the shocking conditions that exist in some institutions for the retarded or severely disturbed has heightened public sensitivity to the care and education of these children. Thus, it becomes increasingly important and urgent to answer such questions as "Why were special classes or special schools set up in the first place?" and "How have American public school policymakers actually viewed retarded or disturbed children?"

In the course of the author's research, the period from approximately the last quarter of the 19th century to the start of World War I was found to be most critical in developing public school involvement with children perceived as mentally retarded or emotionally/ socially disordered. At that time the dominant characteristics took form and stabilized, remaining relatively unaltered through the present.

\section{THE RISE OF SPECIAL EDUCATION}

The period from about 1875 to 1914 established the public school as an integral part of the new, mass-industrialized society. The public school was transformed from a relatively minor social institution, catering largely to the middleclass, to one which was not only available to all levels of society. but which was legally empowered to compel all children to attend. Reflecting the many social and economic changes occurring at this time, the school became the public institution most responsible for the socialization of the American child.

The school's socialization process has been seen as either democratizing and moral or, as critics have argued. constricting and repressive. But it is nearly universally recognized that the school not only provides the child with factual knowledge and skills; it has taken on, with the family, the major role of bringing the child into the general value system and lifestyle of the dominant culture. To accomplish this task, the school has had to either implicitly or explicitly define "normality" in children and, consequently. deviance as well. As we will see, it was this development, perhaps more than any other, that led to the first public school involvement with children viewed today as possessing mental or emotional disabilities.

The growth of the American public school as a major social institution was quite rapid. Between 1852 (Massachusetts) and 1918 (Mississippi), all the states in the Union enacted some form of compulsory school attendance. However, although these laws existed on the books, it was generally not until the 1890s, as Heck (1940) and the Harper Commission Report (1899) pointed out, that such legislation began to be seriously administered and enforced. Soon after, educators were speaking of the need for special classes or special schools for socially unmanageable or mentally deficient children. It does not appear an historical accident that these events occurred at the same time.

In this period. large numbers of nonEnglish-speaking immigrant families from widely divergent ethnic backgrounds had suddenly swept into the cities of the United States. Threatened with the specter of upheaval and disruption, traditional American society turned to the public schools for cultural assistance. Particularly among the oldline cultural and social elite, including educators, it was felt that the immigrant masses must be "Americanized" and brought into the cultural mainstream for the older society to survive. 
For example, professor Howerth of the University of Chicago (1899) argued in the influential Yearbook of the $\mathrm{Na}$ tional Herbart Society llater the Yearbook of the National Society for the Study of Education) under a subheading entitled "socialization the chief aim of education" that

so long as certain classes or certain individuals refuse to recognize their natural relations to society, that is, are unsocialized, so long will they retard the advance of society toward its ultimate goal. The great problem of the age is how to get rid of our unsocial classes. Obviously, the only way to get rid of them is to socialize them. And this may be done by education and this should be, we contend, its main object. (pp. 75-76)

This attitude toward those "certain classes" was salient among the Protestant elite, a group able to make its views felt. In discussing the considerable impact of the Public Education Association (P.E.A.) upon the development of compulsory education in New York City at the turn of the century, Cohen (1964) observed that "its officers and trustees constituted a patriciate of wealthy Protestant families of old American ancestry" (pp. 24-25). Regarding the P.E.A.'s first president, he further noted that "her forbears helped settle New England" and "like other young ladies of her privileged station, Miss Griswold was educated by private tutors at home and by travel abroad" ( $p$. 46). Few of the members of the P.E.A. and similar organizations across the country sent their own children to the public schools. though they were quite concerned that the immigrant children be enrolled by compulsory law.

Summarizing the national trend toward compulsory education in this period, Perkinson (1968) observed:

Only after the Civil War, when the rise of the cities created fears for the stability of society, do we find any widespread effort to secure effective compulsory education laws. Four years after the passage of the 1875 compulsory education law in New
York the state superintendent reported that the law was effectively enforced in only New York City and Brooklyn. The same urban character of compulsory education is evident in the first law of Maryland, which applied only to Baltimore and populous Allegheny County. In Missouri school attendance was made compulsory from eight to fourteen only in cities with a population over 500,000. The city child, especially the child of the newcomers. had generated both compassion and fear. He was unkempt, uncared for, and untutored. He was in need of help. But he was also a threat. ... Partly from fear and partly from compassion, thirty-one states enacted some form of compulsory education by law by 1900 . (p. 70)

Once the schools were accorded the public responsibility of socializing and educating huge numbers of children. many from foreign-speaking backgrounds, they were faced with an unanticipated problem: what to do with those children who, for whatever reasons, could not be handled within the regular classes. A clear exception, it should be pointed out, were the most severely deviant children-they were viewed, and have been until quite recently, as rightfully belonging in state custodial institutions. In discussing the importance of the development of compulsory education upon school involvement with children perceived as "exceptional," Heck (1940) noted:

Public education did not take much interest in such special schools or classes until compulsoryattendance laws came into being. These laws forced all children of given ages into school; this brought to the attention of educators a group of children who for various reasons had previously been eliminated at an early age; they had not, therefore, caused the schools any trouble. (p. 21).

The child with minimal academic ability or interests, for example, dropped out of school in the earliest grades, or else was never enrolled in the first place. As for the children called "incorrigible" (those today who might be categorized as "emotionally disturbed" or "socially maladjusted"), it seems reasonable to assume that a large part of their defiance was due to their forced, 
unwilling attendance. In any event, few of their number had previously been a matter for the schools to deal with. In this vein, Cremin (1961) commented:

Compulsory school attendance marked a new era in the history of American education. The crippled. the blind, the deaf, the sick, the slow-witted and needy arrived in growing numbers. Thousands of recalcitrants and incorrigibles who in former times might have dropped out of school now became public charges for a minimum period. [emphasis added! (p. 127)

A significant educational event in this period occurred in 1899. when the Educational Commission of the City of Chicago was authorized by the Mayor and City Council to conduct an in-depth study and evaluation of the faltering Chicago school system. Under the direction of W. R. Harper, this report, whose recommendations became a model for many urban school systems in the United States, urged the establishment of special "ungraded" classes and "parental" schools for children who could not be managed within the regular classes. One source quoted by the Harper Report (1899) explicitly related the necessity for creating special educational facilities to the enactment of compulsory schooling regulations:

The Compulsory Attendance Act has for its purposes the reformation of these vicious children. They cannot be received or continued in the regularly organized schools; they were admitted into these schools: they were encouraged to do right: they were reproved: they were punished for misconduct; they have been suspended from further attendance in their classes; their parents cannot or will not control them: teachers and committees fail to correct their evil tendencies and vicious conduct. What shall be done with them? The Compulsory Attendance Act commands that they shall be placed in schools, if not in the regular schools then in other schools to be provided for them. (p. 161)

The Harper Report also quoted one educator of the time who strongly urged that:
By all means the board of education should have the power to establish and maintain one or more of such schools, and thereby break up or avoid the formation of bad habits and character. and thus save many children from becoming criminals.... We should rightfully have the power to arrest all the little beggars. loafers and vagabonds that infest our city, take them from the streets and place them in schools where they are compelled to receive education and learn moral principles. (pp. 163-164)

Who were these "vagabond" children, seen to pose such a threat to the city? Who were their parents, viewed by school officials as uncooperative and unresponsive? Hawes (1971) noted that "in the 1890's most of the juveniles arrested by the police of Chicago were the children of immigrants" (p. 161). Not only did the presence of the immigrant child catalyze the development of compulsory education in the United States, but it directly influenced the establishment of special education as well.

It is important to recall just how strongly the immigrant population affected the public schools in the period from the late nineteenth century to the start of World War I, when immigration to the United States was virtually cut off. In 1909, when the U.S. immigration Commission conducted its massive study, $57.8 \%$ of children in the public schools of the 37 largest American cities were of foreign-born parentage. In New York City, the figure was $71.5 \%$, in Chicago, 67.3\%, in Boston, 63.5\%. As late as 1917, immigrant children comprised $70 \%$ of public school enrollment in New York City (Cremin, 1961). Such children posed extreme administrative problems to the school and, as a result. special educational facilities were frequently a hodgepodge bin. disproportionately filled with immigrant children. H. A. Miller (1916) described this situation in the Cleveland schools:

At the present time such cases are often handled in a most unsatisfactory manner. The non-English 
speaking child cannot keep up with his companions in the regular grades. For this reason he is sent to a special class, but if there is not a steamer class available, the pupil is all too frequently assigned to the backward class. This is not because the backward class is the right place for him, but rather because it furnishes an easy means of disposing of a pupil who, through no fault of his own, is an unsatisfactory member of a regular grade. (p. 74)

In the same report, the author cited an earlier study conducted for the Cleveland schools which found that mentally retarded children were being placed in foreign-speaking classes and that normal foreign children were being assigned to classes for the mentally deficient. This unfortunate development was attributed largely to faulty diagnosis and poor administration. Earlier, in 1902, the Supervisor of Primary Schools in New Haven, quoted by the Connecticut Special Education Association (1936), noted that their ungraded classes were receiving three distinct groups of children who were being lumped together in the special classes: "incorrigible boys, defective children, and children who speak no English" (p. 23).

\section{THE IMPACT OF SOCIAL DARWINIST THOUGHT}

During this period, societal as well as professional attitudes toward the education of the mentally or socially variant child were greatly influenced by Darwinist theory. While not universally shared, this orientation was nevertheless dominant among the American intelligentsia and main culture-bearers, including educators.

The leading social philosopher of the English-speaking world at this time was Herbert Spencer, whose influence during the period from about 1870 to 1890 was unequaled. Hofstadter (1959) noted that "Spencer's philosophy ... gave Spencer a public in- fluence that transcended Darwin's" (p. 31 ), and "in the three decades after the Civil War it was impossible to be active in any field of intellectual work without mastering Spencer" (p. 33). Basing his theories on Darwin's biological formulations, Spencer developed a philosophy of social selection which argued that only the most fit of the human species should be permitted to survive, so that mankind as a whole might advance; the weaker members of humanity, through their innate inferiority, detracted from the biological progress of the race and hence posed a threat to the future of mankind. Consequently. Spencer condemned not only poor laws but also public health and public educational facilities, since these institutions sustained many of the individuals seen as innately inferior. Eventually, it was believed, nature would weed out through natural selection all such undesirables, and there would be no further social problems.

The major spokesman for Social Darwinist thought in the United States was William Graham Sumner of Yale. Synthesizing Darwinian theory with traditional Protestant ethic values. Sumner argued that social, as well as biological, inequality was an inevitable law of nature, that without it the law of survival could have no meaning. The rich were "that way" because of their superior natural acumen and intelligence: the poor and infirm were simply those members of the species who had lost out in the evolutionary race owing to their innate disabilities. To attempt a program of public aid for such persons was deemed ridiculous as well as grossly unscientific. What was logical and sensible, according to Social Darwinist thought, was eugenics.

Regarding the mentally retarded or behaviorally deviant child, the impact of 
these views upon popular and professional opinion was considerable. The general attitude toward such persons became one of fear and alarm rather than sympathy or benevolence, and this feeling carried over into the field of education. Thus, in a report to the New York City Commission on School Inquiry, Paul Hanus, a well-known professor of education at Harvard and editor of World Book Company's new "School Efficiency Series," warned that the two most pressing problems facing the New York City public schools were those posed by the "persistently unruly child" (p. 18) and the mental defective. Hanus (1913) stated:

Such persons not only become a burden to society themselves. but propagate their kind in large numbers by marriage or illegitimate unions with each other or normal individuals. .. Whatever it costs, the city cannot safely perpetuate the inadequate measures of discovering and caring for its mentally defective children, and run the further risk of allowing the present progressive increase of mental defectives to continue unchecked. (pp. 2021)

This sort of attitude toward the mentally retarded was significantly encouraged by the writing of Henry $H$. Goddard, one of the major figures in special education in the first two decades of the 20th century. It was Goddard who. in 1908, as Director of Research at the Training School in Vineland, New Jersey, translated into English the Binet intelligence tests and made the first adaptations for their use with children in the United States. Establishing, too, the first psychological laboratory for the study of the mentally retarded. Goddard today is generally venerated as a heroic figure of this period. For instance, the Journal of Special Education (Fall 1971) wrote of him, "His talent in its manifold expressions helped direct special education into the channels of its twentieth-century growth" (p. 210). Without disparaging any of his achievements, it may prove useful in our understanding of this era to briefly review his philosophy toward the mentally or socially variant child.

According to E. E. Doll (1967), Goddard's first major work. The Kallikak Family (1912) triggered a "wave of eugenic alarm." His description of the Kallikak family depicted the "feebleminded" as a social menace which threatened the future of the human race. It was from the genetic stock of the mentally deficient that criminals, paupers, drunkards, and other social undesirables arose, contended Goddard. If allowed to breed unchecked, he reasoned, they would produce even more of their kind. In 1916, in Feeblemindedness, he advanced the argument that social problems in the United States were caused by individuals who, because of their innate mental deficiencies, were unable to cope with the complexities of contemporary life. It is interesting to note the Puritan ethic in Goddard's thinking: $\mathrm{He}$ considered prostitution and intemperance as among the greatest dangers facing society. And, finally, as late as 1921 , he argued for the extreme Darwinist view of mental retardation and behavioral deviance when he wrote in his book. Juvenile Delinquency:

There are two million people in the United States who, because of their weak minds or their diseased minds, are making our country a dangerous place to live in. The two million is increasing both by heredity and by training. We are breeding defectives. We are making criminals. (p. iv)

In a separate chapter entitled "The School's Opportunity to Prevent Delinquency." Goddard cited statistics showing that $13 \%$ did not get above the fourth grade, another $13 \%$ did not get above the fifth grade, and so forth. $\mathrm{He}$ went on to argue that the reason for this attrition was that "each group has 
reached the limit of its intelligence" (p. 116). Children viewed by school administrators as socially maladjusted, Goddard explained, suffered from innate mental deficiencies and "primitive instincts" like sexuality or aggressiveness. which led them to their anti-social activities. If necessary, he stated, such youths should be placed in permanent state custody and sterilized.

Goddard's writings were extremely influential at the time and widely accepted by both professionals and the lay public. Cohen (1964), for instance, reported that his positions had considerable impact upon the previously mentioned Public Education Association (P.E.A.) of New York City, a powerful lobby of the corporate and cultural elite. The mentally retarded and socially maladjusted were viewed at best as poor unfortunates who, through no fault of their own, were a menace to society and to the betterment of the human race; their inferior hereditary makeup could not be overcome and, unless checked, they would pass on their bad genes to unborn generations. At worst. the general attitude at this time was one of hysteria and fear, and the establishment of special school classes or institutional structures for these children must be seen against this attitudinal backdrop.

\section{DISCUSSION}

Public school involvement with children viewed as mentally or emotionally impaired is under unprecedented criticism today. In recent years. members of minority groups, child advocates and, increasingly, professionals themselves have begun to challenge traditional public school assumptions and practices toward these children. In particular, it is pointed out that children labeled mentally retarded or emotionally disturbed/socially maladjusted tend to be disproportionately from poor, nonwhite backgrounds (Dunn, 1968; Mercer, 1971; Ross, DeYoung, \& Cohen, 1971). Their labels are seen as stigmatory and largely reflections of only their inability to conform to white, middle-class values and behavioral traits. Representing such contentions, Johnson (1969) commented that

special education is helping the regular school maintain its spoiled identity when it creates special programs (whether psychodynamic or behavioral modification) for the 'disruptive child' and the 'slow learner', many of whom, for some strange reason. happen to be black and poor and live in the inner city. (p. 375)

Currently, too. many Chicano and Puerto Rican, as well as Black, parents and supporters charge that their children are unfairly placed in classes for the mentally retarded or emotionally disturbed, simply because of their different language or dialect. But, until now, such criticism has lacked an historical basis.

It is extraordinary to observe that virtually the identical kinds of criticism were leveled, frequently by school officials themselves, against the "ungraded" classes of the immigrant period reviewed in this paper. Said officials noted the widespread mislabeling of foreign-speaking children as mentally deficient; today, it seems clear as well that many of the East European children considered to be "unsocialized" or "incorrigible" simply represented manners. values, and attitudes divergent from those of the public schools.

The historical parallels are striking. Seventy and eighty years ago. as we have seen, special school facilities for children viewed as mentally retarded or behaviorally disordered were explicit/y established to isolate children with whom the regular classes could not cope. Such children, like those in similar programs today, were disproportion- 
ately from poor, non-English-speaking backgrounds. And, from the nature of the comments of school policy-makers at that time, these children were not viewed very sympathetically.

The considerable impact of Social Darwinist thought on educational philosophy and practice during this period is an almost completely forgotten historical force. The dominant attitude. promulgated by men like Henry Goddard, was that the poor and handicapped were as they were because of their innate deficiencies. The mentally retarded and emotionally disturbed were viewed, at best, as poor unfortunates who. through no fault of their own, were biologically unfit to live in modern society or receive a full education. They were to be isolated. prevented from mingling with normal adults and children. At worst, the attitude at this time was one of hysteria and fear, and the establishment of special school facilities for these children must be seen in this historical light.

It is not being argued here that the original motives for public school involvement with such children came solely out of concern for "law and order." There were many individuals. like Elizabeth Farrell, who labored long and energetically out of humanitarian impulses for children viewed as mentally retarded or socially maladjusted. Farrell, for example, became the first president of what is now the Council for Exceptional Children. Nor is it being suggested that, in many instances, such children should not have been separated from the rest of the school children, whom they frequently distracted or terrorized. The immigrant tenement world was indeed often harsh and brutalizing.

Rather, from the material presented here, it seems clear that humanitarian impulses alone cannot explain the sud- den rise of public school involvement with children in these categories. The dominant professional, as well as public, view of mental retardation or social deviance at that time was scarcely one of sympathy or benevolence. It is unlikely that special classes and special schools would have developed as they did, were it not for the East European immigrant deluge which catalyzed the enactment and enforcement of compulsory school attendance laws. These laws, in turn, led to the almost immediate establishment of special school facilities for children disproportionately from poor and foreign background, children whom the regular classes could not handle.

\section{Peferences}

Chicago Board of Education. Fortieth annual report. Public Schools of the City of Chicago. 1894.

Chicago Board of Education. Forty-sixth annual report. Public Schools of the City of Chicago. 1900.

Cohen. S. Progressives and urban school reform. New York: Teachers College, Columbia University Press, 1964.

Connecticut Special Education Association. Development and progress of special classes for mentally deficient children in Connecticut. New Haven: Columbia Printing Company. 1936.

Cremin, L. A. The transformation of the school New York: Alfred A. Knopf, 1961.

Doll, E. In memoriam. The Training School Bulletin, 1957, 54, 48-49.

Doll, E. Trends and problems in education of the mentally retarded. American Journal of Mental Deficiency, 1967. 72(2), 175-183.

Dunn. L. M. Special education for the mildly retarded: Is much of it justifiable? Exceptional Children, 1968, 35, 5-22.

Goddard. H. H. Feeblemindness. New York: Macmillian. 1916.

Goddard, H. H. Juvenile delinquency. New York: Dodd, Mead \& Company, 1921.

Greer, C. The great school legend. New York Basic Books, 1972.

Hanus. P. M. School efficiency, a constructive study applied to New York City. Yonkers, N.Y.: World Book, 1913.

Harper, W. R. The report of the educational commission of the city of Chicago. Chicago: Lakeside Press, 1899.

Hawes, J. M. Children in urban schools. New York: Oxford University Press, 1971.

Heck. A. O. The education of exceptional children. New York: McGraw-Hill. 1940. 
Henry Herbert Goddard (1866-1957), a biographical sketch. Journal of Special Education, 1971, 5, 210 .

Hoffman, E. The treatment of deviance by the education system: History. A Study of Child Variance, Vol. 2. Ann Arbor. Michigan: ISMRRD, University of Michigan, 1973.

Hofstadter, R. Social darwinism in American thought. New York: Braziller, 1959.

Howerth, 1. W. The social aim in education. In C. A. McMurry (Ed.), The fifth yearbook of the National Herbart Society. Chicago: University of Chicago Press, 1899.

Mercer. J. R. Sociological perspectives on mild mental retardation. In H. C. Haywood (Ed.). Socio-cultural aspects of mental retardation. New York: Appleton-Century-Crofts. 1970.
Perkinson, H. J. The imperfect panacea: American faith in education. New York: Random House. 1968.

Platt, A. The child savers: The invention of delinquency. Chicago: University of Chicago Press, 1969.

Ross, S. L., DeYoung, H. G., \& Cohen, J. S. Confrontation: Special education placement and the law. Exceptional Children, 1971, 38, 5-12.

Thompson, F. V. The school as the instrument for nationalization, here and elsewhere. In P. Davis (Ed.), Immigration and americanization. Boston: The Athenaeum Press. 1920.

Wallin. J. E. To set the record straight. Exceptional Children, 1958, 25. 175-177. 